\title{
Rediscovery and redescription of Rhene cooperi Lessert, 1925 (Araneae: Salticidae), another possible mimic of scale insects
}

\section{Переописание Rbene cooperi Lessert, 1925 (Araneae: Salticidae), вероятно ещё один виА, имитируюший щитовок}

\author{
Charles R. Haddad \\ Y.P. ХадАаA
}

Department of Zoology \& Entomology, University of the Free State, P.O. Box 339, Bloemfontein 9300, South Africa. E-mail: haddadcr@ufs.ac.za

KEY WORDS: Aranei, forest, KwaZulu-Natal, South Africa, jumping spider.

КЛЮЧЕВЫЕ СЛОВА: Aranei, лес, Квазулу-Наталь, ЮАР, паук-скакунчик.

ABSTRACT. The South African jumping spider Rhene cooperi Lessert, 1925, described and last collected from a single female specimen almost a century ago, was recently sampled from near the type locality. The female holotype is badly damaged, but the epigynal structure is distinctive and clearly matches the recently collected specimen, which is used to redescribe the species for the first time. The peculiar setation suggests that like the recently described $R$. legitima Wesołowska et Haddad, 2018 and Oviballus vidae Azarkina et Haddad, 2020, this species may also be a mimic of scale insects or lacewing larvae.

How to cite this paper: Haddad Ch.R. 2021. Rediscovery and redescription of Rhene cooperi Lessert, 1925 (Araneae: Salticidae), another possible mimic of scale insects // Arthropoda Selecta. Vol.30. No.4. P.546-550. doi: 10.15298/arthsel.30.4.10

РЕЗЮМЕ. Южноафриканский паук-скакунчик Rhene cooperi Lessert, 1925, описанный по единственной самке собранной почти столетие назад, недавно был собран недалеко от типового местообитания. Хотя голотип сильно повреждён, но форма эпигины достаточно хорошо видна и недавно собранные экземпляры имеют ту же форму. Вид переописывается впервые. Судя по опушению этот вид как и неддавно описанные $R$. legitima Wesołowska et Haddad, 2018 и Oviballus vidae Azarkina et Haddad, 2020, этот вид иммитирует шитовку либо личинок некоторых сетчатокрылах.

\section{Introduction}

South Africa has a very rich spider fauna, with more than 2250 species, but a considerable proportion of these $(\sim 27 \%)$ have never been redescribed, illustrated or are still only known from a single sex [Foord et al., 2020]. This includes a number of species described by Lessert [1923, 1925] from the country, which al- though usually illustrated, are still only known from a single sex.

Rhene Thorell, 1869 is a species-rich dendryphantine genus, currently represented by 65 species from the Old World, of which 13 have been recorded from South Africa [WSC, 2021]. Although most of these species were described during the last decade (e.g. Haddad, Wesołowska [2011]; Wesołowska, Haddad [2013, 2018], eight remain known from a single sex and one was described from a juvenile only ( $R$. foai Simon, 1902). One such poorly known species is $R$. cooperi Lessert, 1925, which was described from a single female and has never been redescribed [WSC, 2021].

Recently, two new salticids, R. legitima Wesołowska et Haddad, 2018 and Oviballus vidae Azarkina et Haddad, 2020, were described from South Africa, and suggested to be mimics of either scale insects (Hemiptera: Coccoidea) or lacewing larvae (Neuroptera: Chrysopidae), due to their white colouration and the presence of peculiar tufts of white setae on the body [Wesołowska, Haddad, 2018; Azarkina, Haddad, 2020]. While describing the latter species, one female specimen with similar colouration and setation from KwaZulu-Natal, South Africa, was found that differed clearly from $O$. vidae in epigynal morphology, with the deeply excavated atrium superficially resembling that illustrated by Lessert [1925] for $R$. cooperi.

After examining the rather severely damaged type specimen of $R$. cooperi (Fig. 1A-D), it was clear that the epigynes of the two specimens were identical. Although the type has lost most of its longer setae, the original description of the species [Lessert, 1925] confirms its pale colouration and the presence of long erect white setae on its body, corresponding to the recently collected specimen. Here a redescription of $R$. cooperi is presented based on the female recently collected from near the type locality. 

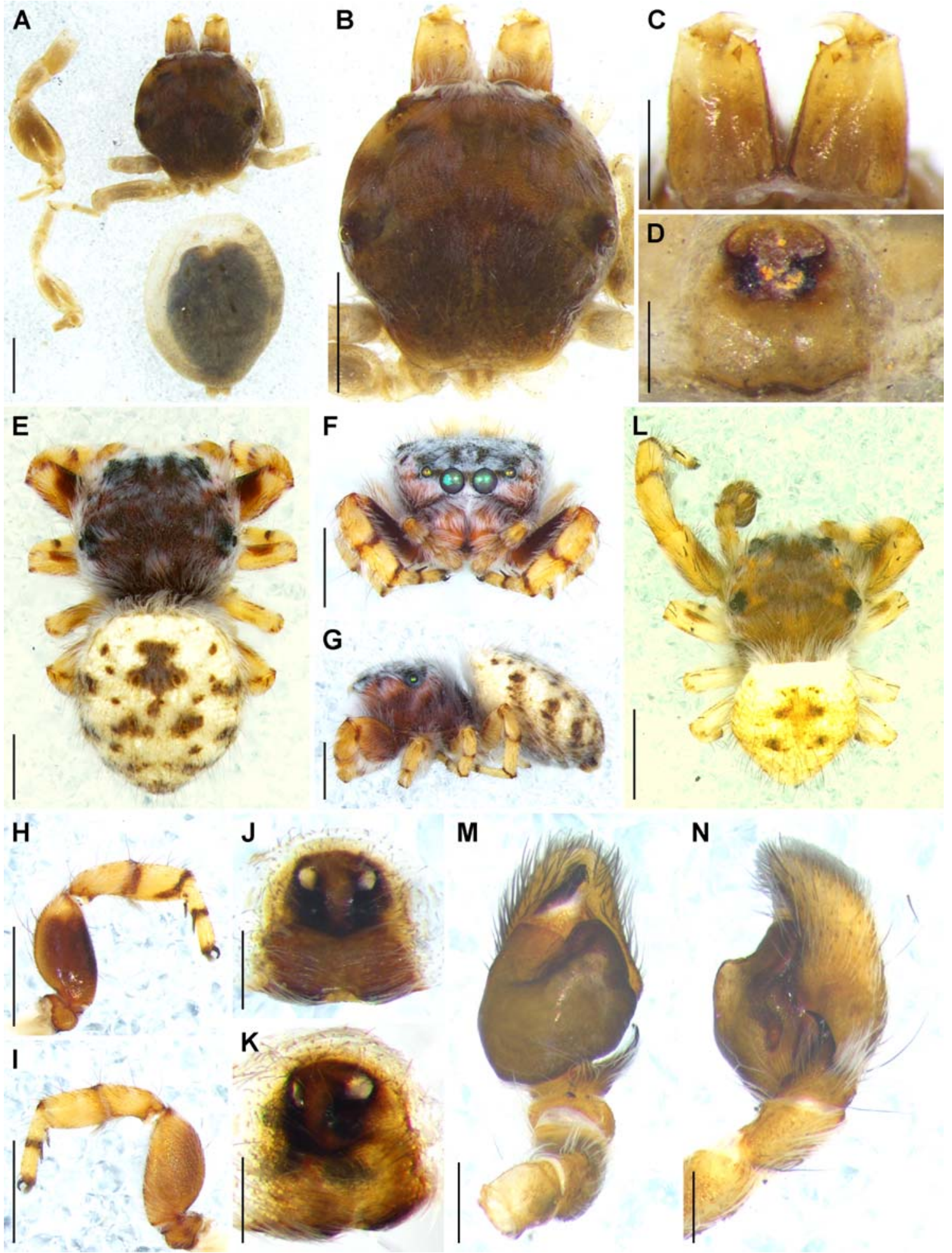

$\mathrm{J}$
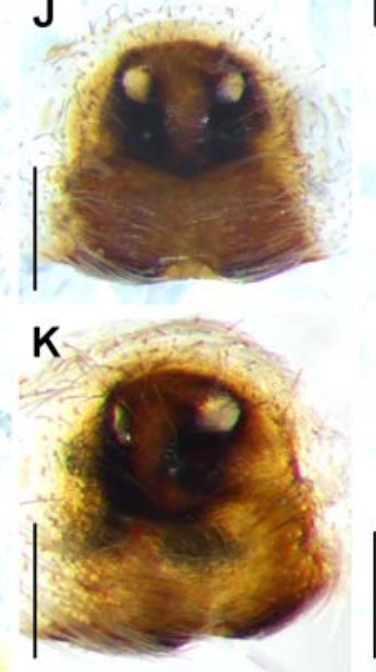

M

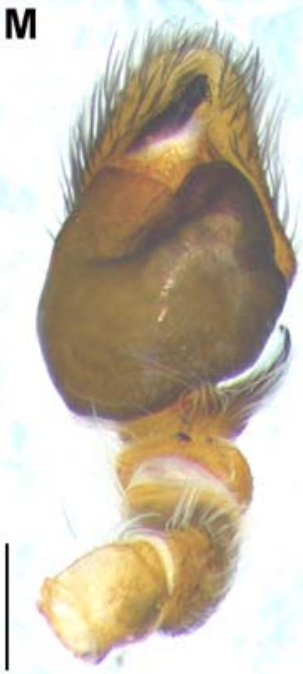

$\mathbf{N}$

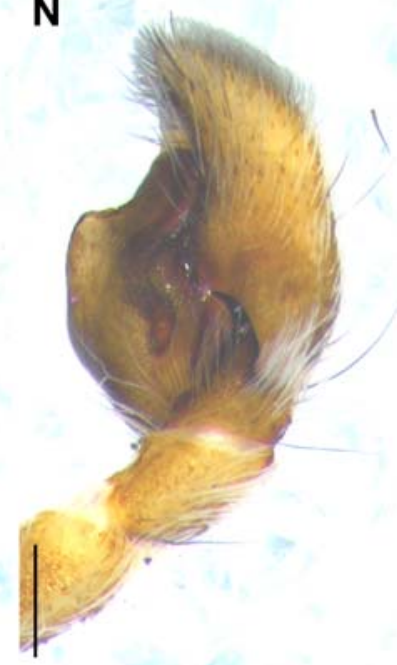

Fig. 1. Somatic morphology and copulatory organs of Rhene cooperi holotype female from Umbilo (A-D), recently collected $R$. cooperi female from Pinetown $(\mathrm{E}-\mathrm{K})$, and $R$. legitima holotype male from Mount Coke $(\mathrm{L}-\mathrm{N})$. A — current state of body parts; B carapace, dorsal view; C - chelicerae, ventral view; D, J - epigyne, ventral view; E, L — habitus, dorsal view; F - carapace, anterior view; $\mathrm{G}$ - habitus, lateral view; $\mathrm{H}-\mathrm{I}$ - left leg I, prolateral and retrolateral view; $\mathrm{K}$ - epigyne, ventrolateral view; $\mathrm{M}-\mathrm{N}$ - left palp, ventral and retrolateral view. Scale bars: A, B, E-I, L $-1.0 \mathrm{~mm}$; C $-0.5 \mathrm{~mm}$; D, J, K, M, N $-0.25 \mathrm{~mm}$.

Fig. 1. Внешний вид и копулятивные органы Rhene cooperi голотипа (A-D) самки из Pinetown (E-K), и самца (голотипа) $R$. legitima из Mount Coke (L-N). A — нынешнее состояние тела; B — карапакс, сверху; C — хелицеры, сзади; D, J — эпигина, снизу; E, L — габитус, сверху; F — карапакс, спереди; G — габитус, сбоку; H-I — левая нога I, спереди и сзади; K — эпигина, снизусбоку; M-N - левая пальпа, снизу и ретролатерально. Масштаб: А, B, E-I, L $-1,0$ мм; C - 0,5 мм; D, J, K, M, N - 0,25 мм. 

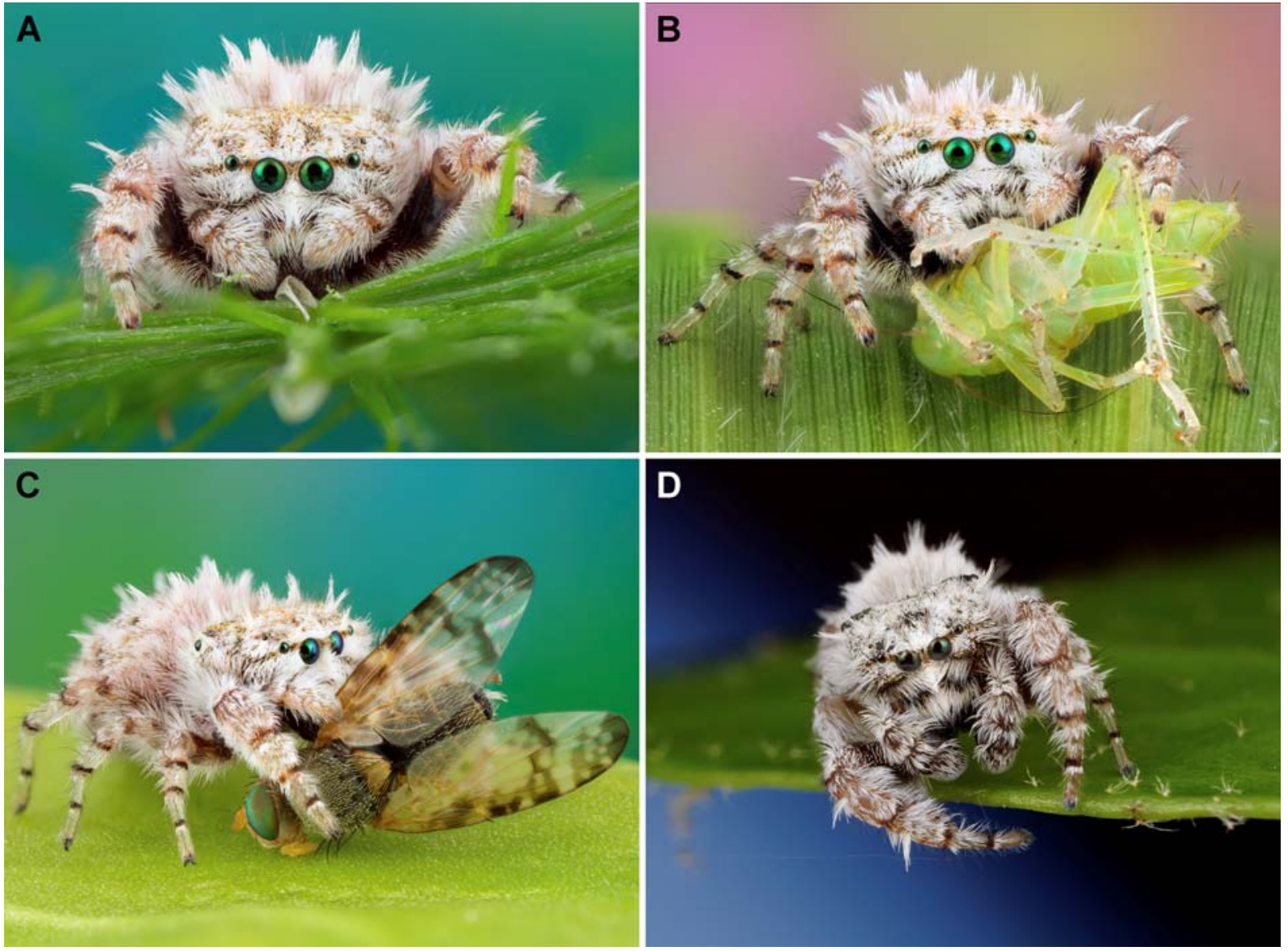

Fig. 2. A-C - habitus of Rhene cooperi female from Pinetown in anterior (A, B) and anterolateral (C) views, feeding on leafhopper (B) and tephritid fly (C); D - habitus of $R$. legitima male from Mount Coke.

Рис. 2. А-C - габитус самки Rhene cooperi из Pinetown спереди (A, В) и спереди-сбоку (C), поедающая цикадку (B) и муху пестрокрылку (C); D - габитус самца R. legitima из Mount Coke.

\section{Material and methods}

The spiders examined in this study were photographed using a Nikon SMZ800 stereomicroscope with an attached Nikon D5-L3 camera system. A series of digital photographs were taken of various aspects of the habitus, legs, chelicerae and genitalic structures of the holotype female (Fig. 1A-D) and a recently collected female (Fig. 1E-K). The photographs were then stacked using CombineZM imaging software (http://www.hadleyweb.pwp.blueyonder. co.uk) to increase the depth of field. The epigyne of the latter specimen was dissected, initially cleaned in a Labcon 5019U ultrasonic bath, and cleared in clove oil for illustration of the internal structure.

For comparison, the holotype male of R. legitima from the Mount Coke State Forest, Eastern Cape, South Africa $\left(32^{\circ} 59.452^{\prime} \mathrm{S}, 27^{\circ} 28.740^{\prime} \mathrm{E}\right)$ was re-examined and photographed (Fig. 1L-N). All measurements are given in millimetres.

The material examined in this study is deposited in the KwaZulu-Natal Museum, Pietermaritzburg, South Africa (NMSA, curator Matabaro Ziganira) and the National Collection of Arachnida, ARC - Plant Health and Protection, Pretoria, South Africa (NCA, curator Petro Marais). The distribution map was created using the online software SimpleMappr [Shorthouse, 2010].

\section{Taxonomy}

Salticidae Blackwall, 1841

Rhene Thorell, 1869

Type species: Rhanis flavigera C.L. Koch, 1846, widespread in southern and south-east Asia.

REMARKS: Rhene is species rich ( 65 species) and widely distributed in the Old World, but the composition and monophyly of the genus has not been investigated phylogenetically. Although the tribe Dendryphantini, to which Rhene belongs, is well supported by molecular data [Hedin, Maddison, 2001; Maddison, Hedin, 2003; Maddison et al., 2014], there are no morphological synapomorphies for the tribe [Maddison, 2015]. For Rhene, the intrageneric and biogeographical relationships of its species are very poorly known, and require urgent study using a representative taxon sample from its broad distribution range. 

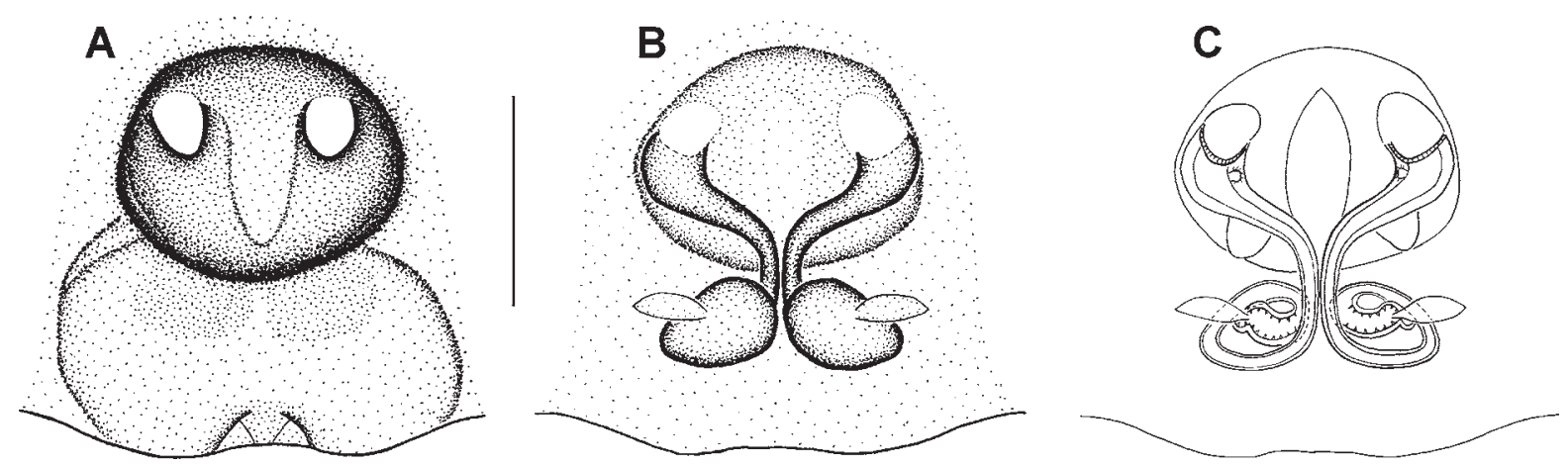

Fig. 3. Rhene cooperi, uncleared epigyne in ventral (A) and dorsal (B) views; C - cleared epigyne, dorsal view. Scale bar: $0.25 \mathrm{~mm}$. Рис. 3. Эпигина Rhene cooperi, непрепарированная снизу (А) и сверху (B); С - мацерированная, сверху. Масштаб: 0,25 мм.

Rhene cooperi Lessert, 1925

Figs $1 \mathrm{~A}-\mathrm{K}, 2 \mathrm{~A}-\mathrm{C}, 3 \mathrm{~A}-\mathrm{B}$.

Rhene cooperi Lessert, 1925: 347, fig. 12.

TYPE MATERIAL. Holotype + : SOUTH AFRICA: KwaZuluNatal Province: Durban, Umbilo, 29 53'S, 3058'E, leg. L. Bevis (NMSA 21128, examined)

MATERIAL EXAMINED. SOUTH AFRICA: KwaZulu-Nata Province: Pinetown, New Germany Nature Reserve, $29^{\circ} 48^{\prime} \mathrm{S}, 30^{\circ}$ 53'E, 6.XII.2016, leg. H. Heron, 1 ㅇ (NCA 2020/201).

DIAGNOSIS. Rhene cooperi shares with $R$. legitima a unique form of body setation, with a dense covering of short white setae and tufts of long white setae on the carapace, legs and abdomen (Fig. 2A-D). Among African congeners, the epigyne of $R$. cooperi most closely resembles that of $R$. konradi Wesołowska, 2009 by the ovoid deep cavity in the anterior of the epigyne and the accessory glands in the initial parts of the copulatory ducts, but can be distinguished from it by the lack of finger-shaped depressions within the epigynal cavity, the gradual divergence of the initial parts of the copulatory ducts (almost immediately converging in $R$. konradi) and the lack of the large posterior notch along the epigastric furrow that is found in $R$. konradi (compare Fig. 3A-C with Haddad \& Wesołowska [2011]: figs 205-206).

DESCRIPTION. Female (NCA 2020/201). Total length 4.80. Carapace 2.20 long, 2.10 wide. Abdomen 2.75 long, 2.15 wide. Ocular area 1.40 long, 1.28 wide anteriorly, 2.13 wide posteriorly. Cheliceral length 0.85 . Clypeus height at AME 0.05, carapace height at PLE 1.20. Diameter of AME 0.32. Length of leg segments: I $1.50,0.78,0.58,0.46,0.44$ (3.76); II $1.02,0.63,0.49,0.47,0.40$ (3.01); III $0.90,0.54$, $0.45,0.52,0.42(2.83)$; IV $1.25,0.65,0.72,0.76,0.45$ (3.83).

Carapace with almost circular cephalic region in dorsal view, thoracic region trapezoidal (Fig. 1B, E). Clypeus very low (Fig. 1F). In lateral view, cephalic region slightly domeshaped, thoracic region with steep slope (Fig. 1G). Chelicerae with bifid tooth on promargin, inner denticle smaller than outer; retromargin with single tooth (Fig. 1C). Abdomen oval, dorsum without scutum (Fig. 1A, E). Leg I stouter and longer than others, with strongly swollen femur (Fig. 1H, I). Leg spination: metatarsus I with 2 pairs of ventral spines, metatarsus IV with 1 prolateral ventral spine.

Colouration (in alcohol, Fig. 1E-G; live, Fig. 2A-C). Carapace deep maroon-brown dorsally, mottled orange-brown laterally; surface densely covered in short white adpressed setae, with scattered long erect brown bristles; 3 tufts of erect long white setae along midline, first at level of PME, second slightly in front of level of PLE, third at front of posterior slope; paired submarginal tufts, each slightly posterior to median tufts; paired lateral tufts to side of PME and in front of PLE. Chelicerae orange-brown; clypeus and basal half of chelicerae densely covered in long white setae, distal half of chelicerae with only few scattered short brown setae. Labium and endites dark brown proximally, orange-brown distally. Sternum dark brown. Abdomen: dorsum white, with scattered dark brown patches, without scutum; densely covered in adpressed white setae, with dense long white setae around anterior margin and scattered long brown bristles throughout. Venter dark grey, with mottled pale grey markings. Legs pale yellow-brown; femur I with large dark brown patch prolaterally, smaller and paler retrolaterally; patches on femora II-IV smaller and paler brown; tibiae and metatarsi all with proximal and distal dark brown rings at joints, also distally on patellae. Palps yellow-brown.

Epigyne with deep broad ovoid anterior cavity, with large curved copulatory openings situated anterolaterally in cavity, separated by distance twice their width (Figs 1D, J, $\mathrm{K}, 3 \mathrm{~A}$ ); copulatory ducts with small accessory glands on their dorsal surface (Fig. 3C), initially directed posteriorly, converging mesally, then forming single loop posteriorly before entering small ovoid spermathecae on mesal margin, slightly broader than terminal width of copulatory duct; fertilization ducts directed laterally, positioned on anterolateral margin of spermathecae (Fig. 3B, C).

Male. Unknown.

DISTRIBUTION. Only known from two localities in the Durban area, KwaZulu-Natal, South Africa. It is possible that the unknown male of $R$. cooperi is in fact conspecific with $R$. legitima, but the two species have only been recorded from localities approximately $500 \mathrm{~km}$ apart in southeastern South Africa (Fig. 4). They should remain separate taxa until the unknown opposite sex of either species is discovered to confirm this suspicion.

HABITAT AND BIOLOGY. To date, $R$. cooperi has only been collected from two nearby localities falling within the Indian Ocean Coastal Belt biome of South Africa, consisting predominantly of remnant coastal forest patches within urban areas. The female specimen photographed (Fig. 2AC) fed on a variety of flies and leafhoppers in captivity, so is likely a euryphagous predator in nature. Its colouration and the arrangement of the tufts of long setae on the body are very similar to the male $R$. legitima (Fig. 2D). If these species are confirmed as being distinct and not synonymous when their topotypic unknown opposite sexes are discov- 


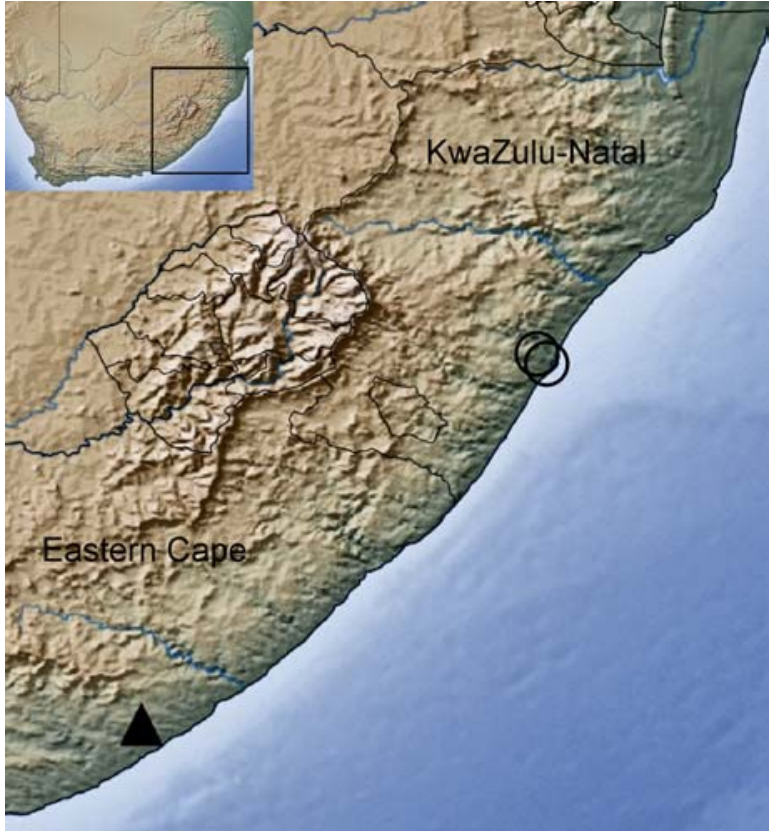

Fig. 4. Distribution of Rhene cooperi (open circles) and $R$. legitima (triangle) in South Africa.

Рис. 4. Распространение Rhene cooperi (круги) и R. legitima (треугольник) в ЮАР.

ered, there will be three jumping spiders that are mimics of either scale insects (Hemiptera: Coccoidea) or lacewing larvae (Neuroptera: Chrysopidae).

The possibility of the former insect being the model is supported by Oviballus vidae being regularly collected from plants with woolly scales, although the movements of $O$. vidae quite closely resemble those of chrysopid larvae. In fact, a fourth species of possible scale mimic, a new Rhene species, was recently discovered in a collection of salticids from southern Mozambique [Wesołowska, Haddad, unpubl.], indicating that this phenomenon may be more widespread than has previously been known or even suspected. This adds to an already interesting modification of body forms in the genus Rhene, which also includes a mimic of vespid wasps [Radjashekhar, Siju, 2003] and mimics of beetles [Maddison, 2015].

Acknowledgements. Matabaro Ziganira (NMSA) kindly loaned the type specimen of $R$. cooperi, and Vida van der Walt provided the specimen collected by Hugh Heron for examination, as well as her beautiful photographs of $R$. cooperi and $R$. legitima. Burgert Muller kindly identified the fly prey in one of the photographs. Galina Azarkina (Novosibirsk, Russia), an anonymous reviewer, and editor Yuri Marusik (Magadan, Russia) kindly provided remarks that improved the manuscript. This study was funded through a grant from the National Research Foundation of South Africa (\#132687).

\section{References}

Azarkina G.A., Haddad C.R. 2020. Partial revision of the Afrotropical Ballini, with the description of seven new genera (Araneae: Salticidae) // Zootaxa. Vol.4899. No.1. P.15-92.

Foord S.H., Dippenaar-Schoeman A.S., Haddad C.R., Lyle R., Lotz L.N., Sethusa T., Raimondo D. 2020. The South African National Red List of spiders: patterns, threats, and conservation // Journal of Arachnology. Vol.48. No.2. P.110-118.

Haddad C.R., Wesołowska W. 2011. New species and new records of jumping spiders (Araneae: Salticidae) from central South Africa // African Invertebrates. Vol.52. No.1. P.51-134.

Hedin M.C., Maddison W.P. 2001. A combined molecular approach to phylogeny of the jumping spider subfamily Dendryphantinae (Araneae, Salticidae) // Molecular Phylogenetics and Evolution. Vol.18. No.3. P.386-403.

Lessert R. de 1923. Araignées du sud de l'Afrique // Revue Suisse de Zoologie. T.30. Fasc.1. P.161-212.

Lessert R. de 1925. Araignées du sud de l'Afrique (suite) // Revue Suisse de Zoologie. T.32. Fasc.1. P.323-365.

Maddison W.P. 2015. A phylogenetic classification of jumping spiders (Araneae: Salticidae) // Journal of Arachnology. Vol.43. No.3. P. 231-292.

Maddison W.P., Hedin M.C. 2003. Jumping spider phylogeny (Araneae: Salticidae) // Invertebrate Systematics. Vol.17. P. 529-549.

Maddison W.P., Li D.Q., Bodner M.R., Zhang J.X., Xu X., Liu Q.Q., Liu F.X. 2014. The deep phylogeny of jumping spiders (Araneae, Salticidae) // ZooKeys. Vol.440. No.4. P.57-87.

Radjashekhar K.P., Siju K.P. 2003. Pretending to be a predator: wasp-like mimicry by a salticid spider // Current Science. Vol.85. No.8. P.1124-1125.

Shorthouse D.P. 2010. SimpleMappr, an online tool to produce publication-quality point maps, online at http://www. simplemappr.net, accessed on 7.6.2021.

Wesołowska W., Haddad C.R. 2013. New data on the jumping spiders of South Africa (Araneae: Salticidae) // African Invertebrates. Vol.54. No.1. P.177-240.

Wesołowska W., Haddad C.R. 2018. Further additions to the jumping spider fauna of South Africa (Araneae: Salticidae) // Annales Zoologici, Warszawa. Vol.68. No.4. P.879-908.

WSC. 2021. World Spider Catalog. Version 22.0. Natural History Museum Bern, online at http://wsc.nmbe.ch, accessed on 7.6.2021.

Responsible editor Yu.M. Marusik 